\title{
Decolonizing Deliberative Democracy: Perspectives from Below
}

\author{
Subhabrata Bobby Banerjee ${ }^{1}$ (D)
}

Received: 24 August 2020 / Accepted: 10 October 2021 / Published online: 16 October 2021

(c) The Author(s) 2021

\begin{abstract}
In this paper I provide a decolonial critique of received knowledge about deliberative democracy. Legacies of colonialism have generally been overlooked in theories of democracy. These omissions challenge several key assumptions of deliberative democracy. I argue that deliberative democracy does not travel well outside Western sites and its key assumptions begin to unravel in the 'developing' regions of the world. The context for a decolonial critique of deliberative democracy is the ongoing violent conflicts over resource extraction in the former colonies of Africa, Asia and Latin America. I argue that deliberative democracy cannot take into account the needs of marginalized stakeholders who are defending their lands and livelihoods. The paper contributes to the literature by (1) offering a critique of hegemonic models of democracy that cannot address issues of inequality and colonial difference and (2) offering possibilities to imagine counterhegemonic alternatives for a democratization of democracy from below.
\end{abstract}

Keywords Deliberative democracy $\cdot$ Decoloniality $\cdot$ Indigenous struggles $\cdot$ Postcolonialism $\cdot$ Corporate social responsibility

'The notion of One-World World signals the predominant idea in the West that we all live within a single world, made up of one underlying reality (one nature) and many cultures. This imperialistic notion supposes the West's ability to arrogate for itself the right to be "the world" and to subject all other worlds to its rules, to diminish them to secondary status or to nonexistence, often figuratively and materially. It is a very seductive notion. Arturo Escobar

The master's tool will never dismantle the master's house. Audre Lorde

Subhabrata Bobby Banerjee bobby.banerjee@city.ac.uk

1 Bayes Business School, City, University of London, London, UK
Most contemporary Western scholarship on business-society relationships tends to either ignore colonialism or relegates it to the margins. As an epistemic critique of knowledge about management postcolonialism calls attention to the absences of voices from the global South in the production of management knowledge (Alcadipani et al., 2012; Srinivas, 2020). Critical management scholars have used insights from postcolonialism to investigate neo-colonial power structures in a variety of contexts (Banerjee \& Prasad, 2008; Jack et al., 2011; Prasad, 2003; Westwood, 2006; Westwood \& Jack, 2007). Research has investigated the absence of colonial histories in representations of culture in international business, textbooks (Fougère \& Moulettes, 2012); images and representations of 'African' leadership in organization studies (Nkomo, 2011); hybridity in intercultural encounters (Dar, 2014; Frenkel, 2008; Yousfi, 2013); the hegemony of Western epistemology in international management research (Faria et al., 2010; Özkazanç-Pan, 2008); colonial complicities in business school education (Boussebaa, 2020; Dar et al., 2020); race and racism in the elite postcolonial world of high finance (Prasad \& Qureshi, 2016); identity regulation practices (Boussebaa et al., 2014); neo-colonial influences in processes of globalization and internationalization (Banerjee \& Linstead, 2001; Boussebaa et al., 2012); and managerial subject formation in a colonial workplace (Srinivas, 2013). 
In the settler colonies of Australia, Canada, New Zealand, South Africa and the United States colonial legacies continue to structure relations between Indigenous communities and multinational corporations. Latin American management scholars have used insights from decolonial thinking to analyze Indigenous struggles against extractive development projects (Misoczky, 2011; Ehrnström-Fuentes, 2016), challenge the epistemic coloniality of North American strategy scholarship (Wanderley \& Faria, 2012), as well as provide Latin American perspectives on international management (Faria et al., 2010) and critical management studies (Mandiola, 2010). Postcolonial critiques of corporate social responsibility (CSR) policies and stakeholder engagement practices in particular have shown how colonial relations dominate deliberative processes of consultation between Indigenous communities and multinational corporations in the extractive industries (Banerjee, 2000, 2008) and in CSR interventions into Third World child labor (Khan et al., 2010). CSR is portrayed as an extension of deliberative democracy where consensus is reached with multiple stakeholders through a deliberative process (Scherer \& Palazzo, 2011). However, in its quest for consensus, deliberative processes elide legacies of colonialism and structural inequalities that persist in contemporary societies. Ongoing conflicts over natural resource extraction in postcolonial states represent a failure of deliberative democracy and reflect patterns of internal colonialism that reinforce colonial modes of extraction. ${ }^{1}$ Conflicts involving the fossil fuel industry in particular are issues of global importance because they have significant implications for climate change.

This paper is motivated by two research questions: In what ways does colonialism continue to cast its shadow in this postcolonial era by masking and subverting emancipatory ideas of democracy? How could a decolonized democracy allow us to imagine a more just and equitable society? This paper's main contributions are to offer a critique of deliberative democracy from a decolonial perspective and suggest possibilities to imagine counterhegemonic alternatives for a democratization of democracy from below. My aim is to provide new insights from a decolonial perspective that can change the conversation about deliberative democracy.

The paper is structured as follows. I begin with a critical analysis of the core concepts of deliberative democracy and describe some of is contradictory outcomes for the postcolonial world. Second, I trace the colonial past of democracy

\footnotetext{
1 There are more than 3000 ongoing conflicts involving the extractive industries (mining, gas and oil) and communities impacted by extractive activity. Almost all of these conflicts involve Indigenous communities in the postcolonial countries of Africa and Asia and in the settler colonies of Australia, Canada, New Zealand, United States and Latin America (EJOLT, 2020).
}

ideals and highlight its presence in contemporary neocolonial institutions and structures. Liberal notions of democracy arising from the Enlightenment era were underpinned by capitalist ideals and a colonial rationality that privileged and universalized Western notions of property. For example, individual property rights were legitimized while delegitimizing communal land usage, which was the norm for Indigenous populations, who were portrayed as 'premodern' and 'primitive' by Enlightenment thinkers (Dhawan, 2014). Third, inspired by Latin American scholars and activists, I describe the decolonial project as an attempt to envision alternate perspectives that can 'displace Western rationality as the only framework and possibility of existence, analysis and thought' (Mignolo \& Walsh, 2018, p. 17). Fourth, using the Dakota Access Pipeline (DAPL) protests as an illustration, I show how contemporary organizational practices, in particular processes of land acquisition by multinational corporations in the extractive industries enabled by state power, continue to be informed by colonial and racial hierarchies despite their claims of promoting deliberative democracy. I conclude by discussing the implications of a decolonial critique of deliberative democracy for business ethics and outlining future research directions that can explore alternate social and political imaginaries.

\section{The Contents and Discontents of Deliberative Democracy}

The year 2019 will be remembered as the year of protest with millions of people taking to the streets in Africa, Asia, the Americas and Europe to express their frustration with their political leaders. We appear to be in the middle of a democratic recession: approval ratings for most politicians and political parties across the world are abysmal, there are deep divisions in most Western democracies, and public trust in democratic institutions are at record lows (Fishkin $\&$ Mansbridge, 2017). The democratic boom following the wave of political decolonization in the 1950s and the end of the Cold War appears to be well and truly over with the rise of authoritarianism, social unrest, state repression of dissent, increasing human rights violations, government crackdown on free speech, violent conflicts over natural resource extraction and an increase in modern slavery, all of which are happening in 'democratic' countries (Amnesty International, 2019). Democracy, or at least the model of dominant party system representative democracy in Europe and the United States appears to be under threat.

The recognition that in modern liberal Western democracies formal democracy through majority rule precluded genuine participation of citizens led to a 'deliberative turn' in democratic theory in the late 1980s and early 1990s. The deliberative turn, pioneered by the philosophies of Habermas 
and Rawls and further elaborated by political theorists like Cohen, Dryzek, Fishkin, Gutmann, Mansbridge, and Thompson among others, began as a normative project that focused on deliberation as an ideal rational discourse where consensus was reached freely and without coercion. Political legitimacy was thus established through deliberative processes that reflected the discursive quality of decision making rather than representation through voting. Rationality of a democracy according to Habermas $(1975$, p. 32) was less about majority rule, which could not represent the interests of all citizens, but should be based on the 'genuine participation of citizens in political will formation.' Thus, more participatory forms of democracy required a deliberative ideal involving a discursive process where citizens could freely communicate as equals to arrive at a rational consensus on decisions affecting their lives.

Merely acknowledging differences and inequalities does not make them disappear. Rather than seek an authoritarian consensus, a truly deliberative framework would need to accommodate conflict and dissent as well. Mouffe (1999) argues that a preoccupation with procedural issues relating to consensus depoliticizes the public sphere and that a robust and vibrant public sphere needs to embrace conflict and dissent. A more radical and progressive democratic politics would transform antagonism into 'agonistic pluralism' where political contestations reflect not 'antagonism between enemies but agonism between adversaries' (Mouffe, 1999, p. 754). The aim is to 'domesticate' destructive antagonism into a constructive agonism where democratic decisions may or may not be fully consensual but can also respectfully accept unresolvable disagreements' (Hillier, 2003, p. 42). Or as Foucault (1984, p. 379) puts it 'one must not be for consensuality, but one must be against nonconsensuality.'

Deliberative democrats have acknowledged these critiques and attempted to broaden the scope of deliberative democracy to accommodate exclusions and inequalities. For instance, consensus - the desired outcome of deliberation-was seen as not always desirable even when possible (Gutmann \& Thompson, 2018). Habermas's later work also adopted a more flexible approach, acknowledging that 'in the case of controversial existential questions arising from different worldviews even the most rationally conducted discursive engagement will not lead to consensus' (Habermas, 2001, p. 43). The task then of a successful deliberative politics is to institutionalize appropriate procedures that can enable rational discourse among informed publics. This 'public sphere' is the institutionalized discursive space where ordinary citizens could deliberate about politics, the economy, and other issues that affected their lives. Habermas's notion of a public sphere was based on a historical analysis of the emergence of new forms of public interaction that took place in coffee houses, salons, and public squares during the eighteenth and nineteenth centuries. However, feminist and postcolonial scholars have critiqued Habermas's notion of public sphere as being exclusionary and lacking in open access, participation and social equality that are key to democratic deliberation. If the public sphere was the space where consensus was being manufactured it becomes a new site of hegemonic domination (Fraser, 1990). The merchants and intellectuals who deliberated in cafes and salons about the weighty political and social issues of their time would in all probability have not appreciated the fact that the coffee they consumed was produced by slave labor in the colonies (Eze, 1997). Moreover, as Fraser (1990) points out, opinion forming in the public sphere does not translate into actual decision-making in the political sphere, and even if such an extension were possible it would entrench existing hegemonies and reinforce existing structural inequalities and exclusions.

While ideal conditions of deliberative discourse may exist and enable rational consensus among wealthy residents of suburban Frankfurt or Princeton deliberating about the installation of additional streetlights in their neighborhood, it is difficult to imagine how Indigenous communities in the Brazilian Amazon can engage in deliberative discourse as equal citizens with powerful market and state actors intent on expanding mining and logging on Indigenous lands. Even in urban contexts it would be naïve to expect that citizens can participate as equals, respectfully, and exercise their reason freely given the realities of structural inequalities and discriminations based on race, class, gender and sexual orientation.

Another significant shortcoming in deliberative theories is its lack of a sophisticated analysis of power, which seems to be treated almost like an exogenous variable. The liberal quest for legitimacy seemingly elides notions of power and authority because a key assumption of the deliberative ideal is the absence of coercive power. Legitimacy of a consensus produced by communicative rationality can also be hegemonic because one cannot assume that legitimacy always exists without domination (Clegg, \& Haugaard, 2009; Mouffe, 1999). Some scholars argue that deliberative democracy has a 'nuanced view of power' because it acknowledges that coercive power can exist in deliberative practice (Curato et al., 2017, p. 31). However, they claim it is possible to limit coercive power through good 'procedural design' involving selection of 'less partisan' participants, using independent facilitators or making deliberations public. Such an approach to power is patently unsatisfactory because it elides relationships between power, legitimacy and authority. How does 'procedural design' handle dissent or conflict? And if there is no dissent or conflict in deliberations then has there been an elite capture of the process by excluding or marginalizing dissenting stakeholders? 
Deliberative democrats also assume that power, and sometimes coercion, is needed in a deliberative process, especially when implementing decisions contested by certain groups even if the deliberative process was fair and reasoned (Curato et al., 2017). So the assumption is that the state, the only 'legitimate' source of coercive power, can and should use coercion to implement decisions arrived at in deliberative forums. As we shall see later when we discuss conflicts over natural resources, this is clearly an untenable argument because it legitimizes the use of state violence to implement decisions made in deliberative forums characterized by vastly structurally unequal conditions that disempower marginalized populations. Debates about deliberative democracy elide power dynamics in the broader political economy in which deliberative processes are embedded (Dryzek, 2016). In cases where there are significant power asymmetries and where actions can have serious economic, social and environmental impacts on communities as is the case with extractive industries, procedural design, however carefully designed, cannot accommodate divergent and sometimes incommensurable views on land use. Rather institutional, material, and discursive power that constitute the global political economy determine governance structures and processes of natural resource extraction. These forms of power somehow remain 'outside' of deliberative discourse but create particular forms of legitimacy that deny pluralism of values and rationalities thus marginalizing the legitimate struggles of populations whose values do not conform to the 'norm' (Banerjee, 2018, p. 804).

To summarize: despite its shortcomings there appears to be consensus among scholars in the field that a deliberative process can 'help revive democratic legitimacy, provide for more authentic public will formation, provide a middle ground between widely mistrusted elites and the angry voices of populism, and help fulfill some of our common normative expectations about democracy' (Fishkin \& Mansbridge, 2017, p. 6). But is this optimism unfounded? What are the silences and erasures in deliberative democracy? Are there limits to 'authentic public will formation' and 'democratic legitimacy' that marginalize segments of the citizenry? These are some questions I explore in the next section.

\section{Postcolonial and Decolonial Deliberations}

What is remarkable about the various debates in deliberative democracy is the silence about Western colonialism, especially in Habermas's universalizing notion of communicative rationality. Similar silences can be seen in the work of some Enlightenment thinkers whose concession (and complicity) to slavery and colonialism is paradoxical and puzzling given their proclamations of universal freedom
(Dhawan, 2014; Eze, 1997). Enlightenment reasoning and philosophies of history provided an intellectual justification of more than two hundred years of colonialism. There was little awareness that the much-celebrated use of reason also creates new forms of domination, even more insidious than coercive power because these forms of domination are justified by reason itself (Adorno \& Horkheimer, 1972). Liberal ideas of freedom, progress, development, and democracy are deeply embedded in the idea of Empire, whose mission involved political subjugation of those it sought to empower and civilize without a critical reflexivity of the impact of European colonialism on European philosophy (Banerjee \& Arjaliès, 2021). Even the Frankfurt School, despite its influential work on domination in modern society and critiques of the Enlightenment, is as Said (1993, p. 278) points out 'stunningly silent on racist theory, anti-imperialist resistance, and oppositional practice in the empire'.

It is important we engage with these critiques to arrive at a more nuanced understanding of the complex historical relationships between colonialism and democracy and more importantly identify what traces continue to exist in contemporary political thought. As Fabian (2002, p. 33) points out, good or bad intentions do not alone invalidate knowledge: for that to happen 'it takes bad epistemology which advances cognitive interests without regard for its ideological presuppositions.' And certainly one could argue there is an epistemological closure in EuroAmerican representations of democracy that does not recognize attempts by postcolonial countries to create their own forms of governance consistent with their own conceptions of freedom and rights because they may not conform to 'ideal' standards (Koelble \& Lipuma, 2008). If Enlightenment inspired ideas of democracy elides historical facts about slavery and colonialism then it becomes imperative to reimagine democracy while maintaining the Enlightenment's spirit of critique, or as Marx puts it 'the weapon of the criticism cannot replace criticism of the weapon.'

\section{Settler Colonialism and the (Post)colonial State}

Colonialism was constitutive of European notions of sovereignty, international law and development (Anghie, 2005). International law was deployed to legitimize and facilitate colonial processes and territorial expansion. Discourses of 'civilization' and 'development' for example, created and sustained the binary categories of civilized-barbaric and developed-underdeveloped where sovereignty always remained on the side of the 'civilized' and 'developed' (Banerjee, 2008). Once sovereignty was established along the dimensions of civilization and development, in the postcolonial era the key 'universal' problem was how to create order among newly sovereign states (Anghie, 2005, p. 4). As Hussain (2003) argues, the historical formation of 
colonialism reveals the self-generative epistemic space of the West in its ability to create the rule and the exception, which allowed it to apply sovereignty unequally to newly independent countries. In essence, Third World sovereignty was 'manufactured by the colonial world to serve its own interests' (Anghie, 2005, p. 215).

While colonialism and settler colonialism are related there are important structural differences - the distinction between the colony and metropolitan center is emphasized in colonialism whereas settler colonialism attempts to erase this difference by obscuring the fact that settlement was also invasion (Veracini, 2011, 2013). In the Anglophone settler colonies of Australia, Canada, New Zealand, South Africa and the United States the 'settler revolution' (Belich, 2009) involved the genocide of Indigenous peoples and the repopulation of those regions by European peoples. The term 'settler' belies the violence of settlement and the dispossession of Indigenous peoples. Europeans who arrived in the seventeenth and eighteenth centuries became 'settlers' with permanent land rights displacing (and eliminating) Indigenous peoples who had lived on those lands for many thousands of years. Settler colonialism 'destroys to replace' and can be defined as 'an inclusive, land-centered project that coordinates a comprehensive range of agencies, from the metropolitan center to the frontier encampment, with a view to eliminating Indigenous societies' (Wolfe, 2006, p. 393). The elimination doctrine of settler colonialism was based on race, as was the early immigration policies of the settler colonies, such as the White Australia policy, which was dismantled in stages only after the end of the Second World War. Land appropriation was also justified as being part of the civilizing mission designed to eliminate Indigenous societies, through assimilation, legal domination, and even genocide (Bell, 2016). Among the Aztec, Mayan and Inca societies alone more than 65 million people were exterminated in less than 50 years (Quijano, 2007).

Anglophone settlers were also part of the imperial economic network of goods and resources, which further consolidated their material power. The success of the Anglophone colonial project was also the inspiration for Nazi Germany's plans to remove populations in Eastern Europe to provide land for German 'Aryan' farmers - the 'last great land grab in the long and bloody history of European colonialism' (Tooze, 2006, p. 462). The 'German Hunger Plan' involving forced starvation mirrored policy directives of US government and military forces against Native Americans. Settler colonialism involved the creation of 'neo-Europes' (Crosby, 1986) where the occupation of lands distant from Europe was enabled not just by the arrival of Europeans but also disease spreading microbes, weeds, domesticated plants and animals that accompanied them. European settlers, immune from the new diseases that decimated Indigenous populations, were not just 'silent allies' but an integral part of the colonial weaponizing of diseases like smallpox (Fenn, 2000).

Colonial relations between Indigenous populations and settler states are ongoing and unfinished unlike in postcolonial countries that gained independence from their former colonial rulers (Chen \& Mason, 2019). If the postcolonial moment for the former colonies was independence from foreign rule, for Indigenous peoples in the settler colonies the result was coercive assimilation and the search for ever elusive rights in a 'postcolonial' nation state. Settler colonialism 'was a structure, not an event' in the sense that invasion did not stop after the first moment of occupation but continued through waves of migration with the accompanying imposition of European political, economic and institutional structures on dispossessed Indigenous populations (Wolfe, 2006, p. 397).

The colonial state was the opposite model of the modern European state because colonial subjects were denied citizenship rights at a time when European citizens were being bestowed with social, political and economic rights-as Chakrabarty (2000, p. 4) argues, the 'European colonizer of the nineteenth century both preached Enlightenment humanism at the colonized and at the same time denied it in practice.' Postcolonial scholars argue that Enlightenment ideals of reason, modernity, science and progress were universalized through colonialism and violence. 'Universal' reason privileged Western knowledge systems while delegitimizing local knowledge systems in the colonies: the 'rest' of the world, because it 'lacked' reason could only be constituted as objects of Western knowledge, a process of epistemic violence that devalued and disqualified knowledge possessed by the colonial subject. If the world is knowable only through European categories then certain hierarchies are created through this process of knowing, which as we will see later have always been resisted by the objects of that knowledge. Asymmetrical power/knowledge relations establish and sustain a position of flexible positional superiority that privileges Western scholarship in relation to the Other (Said, 1993). This fixing of difference operates from a privileged position that creates dichotomies of advanced/ backward, developed/undeveloped, modern/primitive that need to be 'managed' by the advanced, developed and modern (Banerjee \& Arjaliès, 2021).

Racial hierarchies also inscribed the logic of colonialism which operated on a system of racial exclusion based on Enlightenment influenced normative criteria that guaranteed political equality to whites while denying the same to nonwhites, the effects of which can still be felt today by Indigenous populations in the settler colonies of the Americas, Australia and New Zealand. Racial hierarchies, empire, territorial expansion, resource extraction and looting that were the hallmarks of colonialism in the eighteenth century evolved into more hegemonic forms of domination through 
discourses of modernization, development and neoliberal globalization which in effect marked 'the continuation of Western imperialism by informal means and through institutions of global governance' (Tully, 2008). Apart from the brutal violence it carried out for more than two centuries colonialism also profoundly transformed social, political and economic relations among governed populations. Divide and rule polices also fragmented Indigenous populations in the Africa, the Americas and Asia thus making the task of managing dissent easier. It should come as no surprise that political elites in postcolonial countries found it beneficial to reproduce colonial modes of governance for both economic and political gain as well as to manage dissenting populations (Koelble \& Lipuma, 2008; Stanley, 2019).

However, postcolonial theory fails to explain contemporary forms of dispossession and violence in postcolonial successors of colonial states in Africa and Asia. Indigenous communities in these newly independent states found themselves under new forms of postcolonial domination especially in their struggles against natural resource extraction from their lands. Extractive modes of development largely remained largely intact, even intensified as former colonies found themselves locked into the development discourse of global neoliberal capitalism. The market-state nexus is a key hegemonic formation in the postcolonial era that created the conditions which enable corporations to extract surplus from resource rich but cash poor communities. In India for example, which has a population of more than 70 million Indigenous people mainly living in resource rich areas, national polices for economic growth have resulted in processes of 'internal colonization' (Shrivastava \& Kothari, 2012) and calls for 'sacrifice zones' in the name of national progress (Temper \& Martinez-Alier, 2013). These 'land wars' are currently taking place in 130 of India's 602 districts with 208 reported conflicts involving Indigenous communities and the state (EJOLT, 2020). Forms of internal colonialism in both postcolonial and settler colonies involve the biopolitical control of populations through prisons, ghettos, policing, state violence, surveillance and criminalization of dissent (Preston, 2013; Tuck \& Yang, 2012).

The postcolonial era appears to have become an era of more efficient colonialism where colonialism has learnt to manage things better by using native elites to take on the role of former colonial administrators. Postcolonialism's preoccupation with culture, past ideological hegemony, regimes of representation, and critiques of European histories however valid, diverted attention from the material conditions of the political economy and the structural inequalities of capitalist relationships (Dirlik, 1994). For subaltern populations struggling against contemporary structures of oppression, sophisticated postcolonial concepts of 'hybridity', 'mimicry' and 'ambivalence' offered little in the way of resistance strategies.
Colonial legacies and the continuing production of inequalities among Indigenous populations in the settler colonies cannot be understood in the grammar of the postcolonial canons that explain colonial histories of Asia and Africa. Describing the Brazilian president Javier Bolsonaro, the Indigenous feminist and human rights activist Rigoberta Menchú Tum K'iche', the cricket captain of Australia (Tim Paine), or the CEOs of Google (Sundar Pichai) and Microsoft (Satya Nadella) as 'postcolonial' may be technically correct but theoretically meaningless (not to mention politically irresponsible). The canons of postcolonialism have, with few exceptions, produced knowledge about the subaltern by following the same colonialist epistemology that it critiqued, instead of knowledge produced with and from a subaltern perspective (Dirlik, 1994; Grosfoguel, 2013). Reconfiguring earlier forms of domination in the language of postcolonialism does not offer radical emancipatory possibilities of creating alternate economic, social and political imaginaries. Emerging scholarship on decoloniality offers some insights on decolonizing both postcolonial studies and democracy as we will see in the next section.

\section{Towards a Decolonial Imaginary}

Scholarship on decoloniality offers a critical perspective where subaltern difference becomes the basis for decolonizing deliberative democracy involving a critical engagement with knowledges and cultural practices that were delegitimized by colonialism (Faria et al., 2010). Decoloniality recognizes the failure of the postcolonial state to live up to the promise of decolonization and interrogates the postcolonial nation state as a colonizing entity in the context of struggles over Indigenous sovereignty' (Banerjee, 2021, p.4). Emerging from Latin America, decolonial scholarship followed a different but related trajectory than postcolonial studies, which was dominated by the work of diasporic South Asian scholars trained in the English literary canons and whose inaccessible writing had little to offer to non-English speaking scholars (Misoczky, 2019). Settler colonialism in the Americas, as we have discussed earlier, differed in significant ways from the predominantly British colonialism in India, the Middle East and Africa, which was the focus of postcolonial studies (Harding, 2017). The fundamental critique of European colonialism by decolonial scholars was similar to what was articulated earlier by postcolonial scholars: the fixing of difference based on a privileged Eurocentric position, racial hierarchies, and the binary categorizations of primitive/modern, developed/underdeveloped, and civilized/barbaric. However, there is a temporal difference: while postcolonial scholarship refers mainly to the nineteenth and twentieth centuries decoloniality begins from the moment of European invasion of the Americas in 
the fifteenth century (Bhambra, 2014). Postcolonial scholarship's obsession with culture and the fetishization of difference also diverted criticism of capitalism and its associated inequalities and forms of oppression, which are central to decolonial thinking (Dirlik, 1994).

Latin American scholars like Aníbal Quijano, María Lugones, Gloria Anzaldúa, Maldonado-Torres and Walter Mignolo among others pioneered scholarship with a decolonial epistemic perspective that takes into account diverse worldviews, particularly of subaltern racial and ethnic populations from the Global South, to produce alternate epistemologies that transcend the Western canon. Colonial difference becomes the basis of the production of these subaltern knowledges resulting in a decolonized epistemology from the perspective of marginalized populations (Mignolo, 2000). The notion of coloniality is inextricably linked with modernity - coloniality is constitutive of modernity and hence 'there is no modernity without coloniality and no coloniality without modernity' (Mignolo \& Walsh, 2018, p. 4). This critical 'border thinking' (Anzaldúa, 1987) is the decolonial response to Habermas's Eurocentric 'unfinished project of modernity' from the perspective of the oppressed and exploited side of the colonial difference (Grosfoguel, 2013, p. 26).

Quijano's $(2000,2007)$ concept of the coloniality of power, which constitutes the global capitalist system in liberal democracies, is central to decolonial thought. Coloniality of power reflects forms of domination that continued in democratic postcolonial countries after the end of direct colonialism, reinforcing historical structural inequalities of the colonial era (Ballestrin, 2015). Coloniality of power is based on a Eurocentric racialized classification of societies that was imposed on Latin America after European invasion: the modernity that was designed to break the shackles of the primitive past of postcolonial countries also embedded them in racial and ethnic hierarchies that constitute the international division of labor (Grosfoguel, 2007; Quijano, 2007). Feminist philosophers have extended decolonial scholarship by drawing attention to the coloniality of gender, which was neglected in initial formulations of decoloniality (Harding, 2017; Lugones, 2010; Manning, 2018). Decolonial feminism requires overturning the coloniality of gender by a critical analysis of the racialized and capitalist forms of gender oppression (Lugones, 2010).

Knowledge production has generally been a one way street where theories that are produced in the 'global North' are imposed on the 'global South' (Alcadipani et al., 2012). Producers of theories, including democratic theories, have generally ignored postcolonial critiques and subaltern theories. This epistemic coloniality inflects theories of democracy in two ways requiring new modes of understanding: first, there is a need to understand how coloniality in democracy produces inequality and injustice, conditions that will always hinder the democratic project. Second, democracy in coloniality requires an understanding of how democracy is used to sustain coloniality (Ballestrin, 2015). This is the essence of the decolonial project. Such a perspective can provide deeper insights into understanding why and how democracies in postcolonial countries 'deviate' from the norm while also understanding how the norm itself is constituted by colonial relations of power. Western powers, to protect their own interests, have exported democracy to nonEuropean sites through soft power using international aid, trade deals, human rights regimes and cultural exchange programs, backed up by military power when these forms of persuasion fail or as Ballestrin (2015, p. 221) puts it, 'when the platforms of democracy and human rights serve to justify contemporary imperial expansion, coloniality is imposed.'

Decoloniality is also rooted in praxis whereas much of postcolonial scholarship is preoccupied with the cultural domain. The starting point for a decolonial praxis is to imagine radically different perspectives that can dislodge Western rationality as the only basis of reality (Mignolo \& Walsh, 2018). This does not mean an outright rejection of Western notions of progress, democracy and development but involves a critical reflexivity that can 'liberate the production of knowledge, reflection, and communication from the pitfalls of European rationality/modernity' (Quijano, 2007, p. 177). Rather than lapse into fundamentalist thinking, a critique of Eurocentric modernity is a project of transmodernity (Dussel, 2012), which involves imagining multiple worlds and forms of democratic alterity as opposed to the global imposition of a single modernity and liberal form of democracy centered in Europe (Grosfoguel, 2013). Transmodern forms of democracy entails decolonizing the racial and capitalist bases of liberal democracy. This epistemological decolonization is a difficult task involving new forms of intercultural understanding that could form the basis of alternate rationalities. Merely bringing in non-Western perspectives into the canon is not sufficient - for example describing an African 'ubuntu' ethics in a European academic journal may qualify as an alternative moral theory but it still fails as a decolonization project because this knowledge is interpellated in Western rules of validation of knowledge and a coloniality of power (Naude, 2019). Perhaps understanding decolonial sites of dissent, resistance, and protest and the multitude of livelihood struggles arising from a politics of difference may enable us to imagine other worlds that are not defined by Eurocentric modernity (Escobar, 2004). Many of these struggles are about a praxis of living and communal organizing that is delinked from the modern capitalist nation state (Mignolo \& Walsh, 2018).

Decoloniality is not the same as political decolonization that occurred during the 1800s in Latin America and the mid twentieth century in Africa and Asia when former colonies gained independence and became new nation states. The 
transition from colonialism to nationalism while marking a postcolonial moment for the nation state excluded large segments of its populations who were now governed by the same rationality and coloniality of knowledge that inscribed the colonial project. Recognition of ethnic minorities among postcolonial nations does not challenge existing power relations or the dominant state model of development. For instance, while the United Nations Declaration on the Rights of Indigenous Peoples guaranteed their economic, cultural and religious rights and the right to strengthen their social and political institutions, it not clear how Indigenous peoples can actually exercise these rights, because as Article 46 of the Declaration states: 'Nothing in this Declaration may be interpreted as implying for any State, people, group or person any right to engage in any activity or to perform any act contrary to the Charter of the United Nations or construed as authorizing or encouraging any action which would dismember or impair, totally or in part, the territorial integrity or political unity of sovereign and independent States'.

However, a decolonial imaginary requires delinking from the 'political unity of sovereign and independent states' because it is this unity that fixes colonial difference within global power structures, disallowing other modes of existence. Any alternative framework must take into account 'the epistemic force of local histories and to think theory through the political praxis of subaltern groups, where the Other becomes the original source of an ethical discourse' (Escobar, 2004, p. 217). In rejecting the universalizing and totalizing claims of Western modernity, a decolonial imaginary does not privilege the nation state as a site for struggle because coloniality ensures that the state cannot be decolonized or democratized (Mignolo \& Walsh, 2018). Instead, the decolonial project is a search for multiple local and regional forms of governance that avoids the pitfalls of undemocratic and repressive regimes which characterize contemporary liberal democracies.

Scholarship on Indigenous sovereignty in Australia, the Americas and New Zealand has challenged dominant narratives about the founding of these nation states and documented how a false political authority was claimed through land that was 'acquired' forcibly or fraudulently and by unilateral extinguishment of native title (Hendrix, 2010). The triumphalist narratives of settler colonial states never pose the key question: 'Where does the force of one law to extinguish the laws of the other draw its legitimacy from'? (Watson, 2006, p. 29). This denial of the original violence of state sovereignty and colonial histories along with an affirmation of Indigenous cultures becomes the basis of Indigenous claims to sovereignty and self-determination (Volmert, 2010). Whether in settler colonies or post-colonial countries, Indigenous groups with distinct preferences and cultures remain marginalized minorities despite being bestowed with 'citizen rights.' Rather than participate in public will formation Indigenous peoples have the will of non-Indigenous citizens imposed on them and only a shift in political authority can change their current situation. While some advocates of deliberative democracy may be 'greatly skeptical about the chances of survival' of Indigenous communities (Benhabib, 2002, p. 185) their ongoing struggles to protect their lands indicate that resistance is fertile (Banerjee et al., 2021). These communities have been fighting to preserve their way of life since the colonial era began and their struggles continue in the postcolonial era. Colonial sovereignties of the modern nation state supersede Indigenous sovereignty and where there is conflict and dissent in deliberative procedures of public will formation the (post) colonial state exercises coercive power to impose the will of 'the people', as I discuss in the next section.

\section{'Our History is the Future'2: Indigenous Struggles as Contested Sovereignties}

Indigenous ${ }^{3}$ communities all over the world bear the brunt of state and market violence. In the postcolonial countries of Asia and Africa, independence from colonial rule meant little to these communities except that their struggles were now against their own (mostly) democratically elected governments rather than their former colonial rulers. In the settler colonies of the Americas, Australia, and New Zealand, Indigenous peoples who had survived genocide, forms of apartheid, and assimilation became interpellated into the modern democratic nation state as second class citizens in their own land. Democratic citizenship for these populations was a violent process because the allegedly emancipatory notions of progress, development, rights, and reason that characterized liberal democracies were profoundly incommensurable with Indigenous worldviews about relationships to land and nature.

In 2007 the United Nations General Assembly adopted the UN Declaration of the Rights of Indigenous Peoples, after decades of activism by Indigenous organizations. In the preamble the declaration affirms that member states are 'concerned that indigenous peoples have suffered from historic injustices as a result of, inter alia, their colonization and

\footnotetext{
2 'Our History is the Future' is the title of a book by Nick Estes that provides a firsthand account of the Dakota Access Pipeline (DAPL) protests.

${ }^{3}$ While there are different definitions of what constitutes an Indigenous person I adopt the view proposed by Sanders (1999, p. 11) who defined Indigenous peoples as 'those ethnic groups that were indigenous to a territory prior to being incorporated into a national state, and who are politically and culturally separate from the majority ethnic identity of the state that they are a part of.' Indigenous peoples constitute 5\% of the world's population but account for $15 \%$ of the 'extreme poor' according to the World Bank.
} 
dispossession of their lands, territories and resources, thus preventing them from exercising, in particular, their right to development in accordance with their own needs and interests' (United Nations, 2007). Article 32 of the Declaration called for consultation 'in good faith with the indigenous peoples concerned through their own representative institutions in order to obtain their free and informed consent prior to the approval of any project affecting their lands or territories and other resources, particularly in connection with the development, utilization or exploitation of mineral, water or other resources.' In the extractives industries the concept of a 'social licence to operate' through consultation with multiple stakeholders is often used as an indicator of community acceptance of extractive projects. However, attempts by companies to obtain a social licence to operate run the risks of co-opting dissenting stakeholders while structural power imbalances ensure that conflicting worldviews remain marginalized (Ehrnström-Fuentes \& Kröger, 2017). Fissures in democratic governance can be seen in ongoing conflicts over resource extraction between Indigenous communities, states and multinational corporations. Between 2002 and $2017,1,558$ people in 50 countries were killed for protecting their lands, forests, water and other natural resources (Butt et al., 2019). About $40 \%$ of those killed belonged to Indigenous tribes in Central America, South America and Asia who continue to face devastating social, cultural, economic, and environmental impacts arising from resource extraction.

While 144 countries have ratified the declaration, Australia, Canada, New Zealand and the United States initially voted against the declaration. Their main reservation was about the 'right to self-determination' and the definition of 'Indigenous peoples.' Since then all four countries have endorsed the declaration with some caveats - Canada described the declaration as 'aspirational,' Australia emphasized that the declaration was not 'legally binding,' while the United States clarified its position on the declaration's 'free, prior and informed consent' by stating 'the United States recognizes the significance of the Declaration's provisions on free, prior and informed consent, which the United States understands to call for a process of meaningful consultation with tribal leaders, but not necessarily the agreement of those leaders, before the actions addressed in those consultations are taken' (US Department of State, 2010; emphasis mine). Colonial state power is clearly evident here: what does 'meaningful consultation' mean when resource extraction projects can still proceed without 'agreement of tribal leaders?'.

The inextricable and contradictory link between sovereignty and colonialism can be seen in the disavowal of Indigenous sovereignty and land rights in Australia and other settler colonies. In the landmark Mabo case when in 1992 the Australian High Court for the first time recognized Aboriginal native title overturning the doctrine of terra nullius (or 'land belonging to no one'), the acquisition of Australia was deemed to be an 'act of state' and Indigenous sovereignty was declared 'non-justicable' (Behrendt, 2003). As Brady (2007, p. 149) points out, for Indigenous peoples in settler-colonial states Western notions of sovereignty represent 'power, imperialism and the unrelenting exercise of colonialism' where citizenship was coercive and involved forced assimilation into the white settler normative framework. Native title in Australia was recognized by the colonial state precisely because it gave itself the power to extinguish it in order to serve interests of mining companies (Banerjee, 2000).

Indigenous views of land as a bundle of relationships stand in stark contrast with the market/state view of land as a bundle of property rights. The structural features of settler colonialism transformed land to property and human relationships to land to ownership, a process that involved 'profound epistemic, ontological, cosmological violence' (Tuck \& Yang, 2012, p. 5). This violence was also deeply racialized: Indigenous people and slaves in the United States were racialized in different ways but with the same goal of ensuring the dominance of white settlers as legitimate occupiers of the land. Classifying African slaves as 'black' or 'colored' had material consequences because their reproduction increased the wealth of slave owners. In contrast, it served the colonial project to racially classify Indigenous people as 'savages' and 'less than human' because it justified the logic of eliminating them and confiscating their lands. ${ }^{4}$ Whether in settler colonies or postcolonial nation states the reality of Indigenous life was a duality between an internal sovereignty constituted by cultural norms that governed Indigenous communities and an external sovereignty of an independent nation state with far greater power and authority and whose values and beliefs were incommensurable with Indigenous cosmologies (Brady, 2007).

The sovereignty of the neoliberal state always prevails over the sacredness and cultural value of land regardless of the types of internal sovereignty or self-governance that may exist in Indigenous communities. Cultural and spiritual

\footnotetext{
${ }^{4}$ Racial hierarchies pervade Enlightenment philosophy. In his early work, Kant asserted that 'Native Americans are the lowest of the four races as they are completely inert, impassive and incapable of being educated.' He placed the 'Negroes' above them as 'they are capable of being trained to be slaves but are incapable of any other form of education.' For Kant, 'the white race possesses all motivating forces and talents in itself.' and 'Native Americans and Negroes cannot govern themselves (they) serve only as slaves' (Kant, 1775/1950; 1776/1978). Similarly Hegel imperiously dismissed all of sub-Saharan Africa because of what he deemed were 'deficiencies of the African spirit', describing Africa as 'this land of children, of barbarity and wildness where no real history can take place. There is no goal, no state there, that one could observe, no subjectivity, but only a series of subjects who destroy each other' (Hegel, 1837/1916).
} 
values of Indigenous peoples are routinely nullified with state power and regulation. For example, in the lawsuit against ExxonMobil following the oil spill from the tanker Exxon Valdez a court ruled (based on 'anthropological evidence' provided by an Exxon-hired anthropologist) that the 'subsistence culture' of the Alutiq people of southern Alaska had not been damaged by the oil spill because 'culture is deeply embedded in the mind and heart.' Consequently there was no loss of cultural resources resulting from the environmental disaster and hence no monetary compensation was required (Temper and Martinez-Alier, 2013). So yet again in liberal democracies colonial power becomes the epistemic basis of a privileged Eurocentric position that can explain culture and define the realities and identities of marginalized populations, while eliding power asymmetries inherent in the fixing of colonial difference. These asymmetries were thrown into stark relief in the protests by Indigenous communities and their supporters over the construction of the Dakota Access Pipeline in the United States during 2016-2017, as we will see in the next section.

\section{Market-State Colonial Violence and The Dakota Access Pipeline Protests}

The resistance movement against the Dakota Access Pipeline (DAPL) by the Standing Rock Sioux tribal nation is an example of how internal colonialism operates in contemporary liberal democracies. The $\$ 3.78$ billion 1,172 mile long pipeline cuts through South Dakota, Iowa, and Illinois to be linked to existing pipelines designed to transport up to 570,000 barrels a day of crude oil. The pipeline passes near the Standing Rock Sioux Reservation in North Dakota whose tribal leaders claim that it would disturb sacred sites, violate past treaties and Indigenous sovereignty and pose grave dangers to the tribe's water supply in the event of an oil spill..$^{5}$ After years of 'deliberations' where the recurring objections of tribal representatives were ignored followed by unsuccessful lawsuits, tribal protestors decided on direct action and set up camp at the site to block construction. The resistance movement caught the national and international imagination with thousands of supporters joining in including environmentalists, climate change activists, Indigenous land rights activists, lawyers, war veterans and Indigenous tribes from other countries. For the first time in more than 250 years all seven bands of the Sioux nation came together to conduct ceremonies to protect their land and water.

Little has changed for Indigenous communities in North America and elsewhere in terms of the colonial relations of

\footnotetext{
${ }^{5}$ Fears over oil spills were not unfounded: In 2017 and 2019 an estimated 590,000 gallons of oil spilled from a leak in the pipeline into agricultural lands and wetlands (Winsor, 2019).
}

power that structure their encounters with the state. Treaties offered little protection to Indigenous lands which for centuries had been taken by force by colonial law enforcement agencies to serve government and private interests. Treaties did not explicitly recognize political sovereignty of Indigenous 'nations' but was a strategy used by the U.S. government to carry out 'land cessions' and justify acquisition of lands that could not be taken by force. This process required an enforceable system of individual property rights, a cornerstone of liberal democracies, where 'settlers' could hold private property in perpetuity whereas Indigenous 'occupancy' was seen as temporary, whose collective ownership could be extinguished for private ownership but not the other way around (Estes, 2019, p. 108).

The long and violent history of colonialism in North America continues to play out today in conflicts over land, water and mineral rights. A major cause of contemporary conflicts is a failure of governance, especially in the reservation system and tribal councils ostensibly designed to give tribes some level of self-governance and autonomy. The breakdown of traditional governance arrangements and the imposition of an electoral system in tribal councils destroyed kinship networks that were fundamental to tribal decisionmaking and governance, creating bitter rivalries between families and communities over access to state and market resources (Estes, 2019). The distinction between 'public' and 'private' spheres, sacrosanct in liberal democracies, is less obvious among Indigenous communities where individual interests are sometimes inseparable from community interests (Koelble \& Lipuma, 2008). Similar neocolonial governance structures were imposed in other settler colonies of Australia, Canada and New Zealand ensuring that Indigenous land and water rights were accorded based on the needs of settlers.

The DAPL protest was not just a fight about water rights but a livelihood struggle to protect a way of life that colonialism had nearly destroyed. The protests were violently quelled by militarized police and private security forces with armored vehicles, rubber bullets, mace, water cannons, attack dogs, tear gas, concussion grenades, armed drones and helicopters. The North Dakota governor declared a state of emergency and called in the National Guard to clear the encampment of peaceful protestors. It is difficult not to see the racialized nature of state violence in quelling tribal protests- these tactics are rarely, if at all used to suppress protests by white American citizens. Tribal leaders also pointed to the racial injustice of the project - an earlier proposal to route the pipeline through Bismarck, a town whose population is $92 \%$ white, was rejected because of risks to the town's water supply.

The DAPL case, like most cases of conflict over land and natural resources involving Indigenous communities reveals the fundamental shortcomings of deliberative democracy in 
its elision of power relations and colonial histories. Advocates of deliberative democracy argue that when the 'democratic process is marked by contentious disagreement, lack of mutual respect, systematic exclusion of disadvantaged individuals and blatant disregard for relevant facts and values, the need for deliberation is greatest' (Gutmann \& Thompson, 2018, p. 902). These conditions certainly apply to the DAPL case but because theories of deliberative democracy cannot meaningfully account for power asymmetries arising from colonial relations, no amount of 'agonistic deliberation' (Brand et al., 2020, p. 3) can overcome a 'market centered stakeholder engagement' (Dawkins, 2015, p. 2) that is the norm in deliberations over land use and natural resource extraction. The 'deliberations' conducted before the decision was made to reroute the pipeline through Indian land (without their consent) typified the 'consultations' that take place between Indigenous communities and market/state actors: Indigenous representatives are allowed a seat at the table but their voices are either not heard or deliberately silenced (Dalrymple, 2016).

In the case of the DAPL protests, violence against the protestors was deployed through a collusion between market and state actors: the owners of the pipeline, Energy Transfer Partners hired the private security firm TigerSwan to conduct surveillance of activists and to provide daily 'intelligence updates' to federal and state law enforcement agencies (Estes, 2019). When the state and big business collude to become legitimate providers of violence in a democracy then that democracy, deliberative or otherwise, must be questioned. Non-deliberative forms of communication like songs and storytelling (both an integral part of Indigenous protests at DAPL), the collective power of social movements, and moral compromise, celebrated by so many deliberate democrats, did not have any material effects but instead the protests were violently supressed by state and market power making a mockery of the 'unforced force of the better argument' (Habermas, 1998, p. 306). Rather, one could reasonably ask as Flyvbjerg (1998, p. 80) does, 'why use the force of the better argument when force alone will suffice' especially when the force is the state acting as the armed enforcement for corporate interests? In the so-called postcolonial era, the justice and police systems in liberal democracies of settler colonies are built on colonial ideals and beliefs that are ultimately meant to serve and protect one segment of society at the expense of another.

Ceremonial elders at the protest camps recalled stories of historical violence and massacres of Native Americans in the area-Wounded Knee and Whitestone where more than 300 women and children were killed by the US military. The 'Indian' wars in North America have never ended and Standing Rock is the continuation of a long history of oppression and violence against Native Americans, an ongoing fight for Indigenous sovereignty over their lands against colonial rule. And this war is also being fought by Indigenous communities in the other settler colonies of Australia, Canada and New Zealand who are resisting resource extraction projects on their lands and fighting for their sovereignty. Dispossession of Indigenous lands is enabled by a disregard for Indigenous land rights and either a lack of consultation with Indigenous peoples or culturally inappropriate and ultimately coercive forms of deliberative consultative processes. In the context of the Indigenous political economy decolonization is not just about equity or social justice or a fight against oppression - it is also about the repatriation of Indigenous land and making 'decolonization accountable to Indigenous sovereignty and futurity' (Tuck \& Yang, 2012, p. 35).

Thus, for many Indigenous communities the issue is not deliberate democracy but Indigenous sovereignty and self-determination, concepts that sit uneasily with liberal democracies. Even enthusiasts of deliberative democracy like Benhabib and Dryzek appear to acknowledge some level of incommensurability in deliberating positions when it comes to Indigenous struggles: short of advocating full Indigenous sovereignty these scholars call for forms of selfdetermination or 'conditional' forms of sovereignty (Dryzek, 2005 , p. 239) where communities can 'negotiate and debate the future of their own conditions of existence' (Benhabib, 2002 , p. 185). Others call for a more radical break from the rights of the state and to create new forms of Indigenous sovereignty based on ownership, authority and self-determination (Forni, 2010). In the concluding section I discuss the implications of decolonial thinking for business ethics.

\section{Implications for a Decolonial Business Ethics}

What are the implications of a decolonial critique of deliberative democracy for business ethics? If as Burg (2009, p. 675) claims the 'objective of a deliberative business ethic is to develop and maintain a normative environment that supports the social and economic functions of commerce' then it is imperative to understand how the coloniality of power constructs particular normative environments. In particular, efforts to democratize deliberative democracy require paying attention to colonial relations of power between different groups rather than seek ways to expand and refine deliberative procedures in different geopolitical contexts. If, as we have seen, deliberative democracy cannot accommodate incommensurable positions then understanding the basis of incommensurability as articulated by 'historically subalternized identities' can provide insights on how democracy can be decolonized from its Western liberal formations (Ballestrin, 2015, p. 217). Such understanding requires an epistemic diversity that will allow us to investigate how different populations conceptualize and experience democracy, 
freedom, rights, development, prosperity and ecology by listening to the demands of voices 'from below', for example, movements like Buen Vivir which emerged from Indigenous struggles against development projects in Latin America and which reflect Indigenous ontologies that require 'the subordination of economic objectives to ecological criteria, human dignity, and social justice' (Escobar, 2015, p. 455). Acknowledging epistemic diversity has to be accompanied by an ontological diversity because Indigenous worldviews are based on a relational ontology where humans and nonhumans co-constitute the world, which is profoundly different from Western realist ontologies based on a human-nature dichotomy (Banerjee \& Arjaliès, 2021). Relational ontologies that underlie Indigenous philosophies of human-nature relationships are also sources of resistance against extractive projects that reflect a 'politics of place' and place related identities of Indigenous communities (Ehrnström-Fuentes, 2019). Here place becomes more than land and territory which are redefined based on the histories of reciprocal relationships between humans, animals, forests, and waters (Ehrnström-Fuentes, 2020). Human-nature relationships are non-hierarchical in a relational ontology and when nature becomes relational and not an entity the dichotomy between humans and nature collapses giving rise to different different realities and meanings of progress and development.

A decolonial perspective also reveals the limits of deliberation at the organizational level. Deliberative democracy has been operationalized at the organizational level through discourses of political corporate social responsibility (PCSR) (Scherer \& Palazzo, 2011), which seems to have as many advocates as critics (Dawkins, 2019; Mehrpouya \& Willmott, 2018). The normative basis of PCSR reflects Habermasian notions of deliberation in its assumption that deliberative processes of corporate engagement with state and civil society actors are desirable because they create a more democratic public sphere. If democracy at the hands of the state has largely failed marginalized populations in the so-called Global South than the perils of handing over democracy to corporations are even more severe. Critics have pointed out that PCSR gives corporations defacto political authority without increasing business accountability (Hussain \& Moriarty, 2018; Willke \& Willke, 2008), undermines democratic legitimacy, (Sabadoz \& Singer, 2017); does not challenge instrumental CSR (Mäkinen \& Kourula, 2012), overemphasizes the effects of globalization (Whelan, 2012) while neglecting the role of the state (Frynas $\&$ Stephens, 2015), and fails to account for structural and discursive power (Banerjee, 2018). In response Scherer et al. (2016) proposed a rebooted version of PCSR 2.0, which while acknowledging some criticisms still failed to provide a sophisticated analysis of power relations that determine the 'political', resulting in a sanitized depoliticized notion of politics as "public deliberations, collective decisions and the provision of public goods' (Scherer et al., 2016, p. 276). PCSR, being derivate of deliberative democracy suffers from the same shortcomings of a communicative process that relies more on procedural design rather than on the power of actors. Multi-stakeholder initiatives (MSIs), like the Forest Stewardship Council and Fairtrade coffee, much lauded by PCSR advocates, are less open processes of deliberative democracy but more a series of hegemonic accommodation to dominant interests (Fougère \& Solitander, 2020; Levy et al., 2016; Moog et al., 2015). At best PCSR is myopic and self-serving, at worst it can be a 'predatory corporate project' (Rhodes \& Fleming, 2020, p. 945) when it is deployed as a weapon to obscure colonial processes of dispossession and violence while providing legitimacy to corporate actors (Alamgir \& Banerjee, 2019; Özkazanç-Pan, 2019; Varman \& Al-Amoudi, 2016).

Decolonial perspectives on deliberation and political CSR can reveal the contested legitimacies that are at the root of conflicts between MNCs and marginalized communities (Ehrnström-Fuentes, 2016; Ibarra-Colado, 2006). Decolonizing PCSR, if that is at all possible, means an engagement with histories of corporate engagement with Indigenous communities. Recent studies however show how continuing colonial narratives inform corporate engagement with Indigenous communities. Analyzing the Hudson's Bay Company's historical engagement with its Indigenous stakeholders, Van Lent and Smith (2020) found that the company's CSR efforts were mainly directed at enhancing its legitimacy by denying claims of 'cultural genocide' in Canada's Truth and Reconciliation report and appropriating Indigenous culture for heritage branding. Similarly, PCSR 'partnerships' with Indigenous communities for resource extraction projects in Canada 'obscure and normalize processes of environmental racism, oppression and violence' (Preston, 2013, p. 43). More research is needed to understand the colonial assumptions underlying PCSR strategies, especially for marginalized populations in deeply divided societies. Under what conditions does organizational deliberation produce negative consequences for its stakeholders? How does deliberative PCSR manage dissent and conflict in its quest for consensus?

A decolonial perspective also requires retheorizing the role of the state in deliberative business ethics. In an era of global neoliberal capitalism the postcolonial nation state is a fundamental building of globalization through its integration in complex global supply chains, facilitating access to multinational corporations, instituting business friendly labor and environmental policies, and expanding extractivism (Ehrnström-Fuentes \& Kröger, 2018; Ong, 2000). In recent years the state in many postcolonial countries has come to resemble more a police state than a democratic state in deploying state violence to suppress dissent among communities protesting resource extractive projects on their lands (Banerjee, 2008). How should multinational corporations (MNCs) 
respond to state violence directed at communities that are stakeholders in their business? How can MNCs respond to increased demands for political autonomy from disaffected populations? What would a 'power-sharing state with attenuated sovereignty' (Dryzek, 2005, p. 218) look like and how should multinational corporations negotiate with states and communities when expanding their business operations?

Decolonial perspectives on deliberative democracy have implications for emerging research on governance in areas of limited statehood in countries where state capacity to govern effectively is compromised by a variety of historical, political and economic factors. In areas of limited statehood governments do not have the capacity and ability to implement and enforce rules of governance or deliver public goods and services in certain parts of their territory, and sometimes even lack their 'legitimate' monopoly over the means of violence due to the active presence of militant groups (Risse, 2011). Deliberate democrats would be nonplussed and more than a little troubled if one described a postcolonial version of a Habermasian public sphere (regions in Afghanistan and Iraq readily come to mind) comprising militant groups, religious leaders, village elders and merchants deliberating in a local coffee shop about the daily violence under US military occupation, the installation of puppet governments, the lack of basic services and the granting of land to Western mining companies for mineral exploration and extraction. A public sphere where militant groups designated as terrorist organizations by the West are seen by local populations as being more legitimate and representative than governments because they deliver public goods and services that the state is unable or unwilling to provide. Governance in areas of limited statehood involve a range of international and national non-state actors (including MNCs) operating at multiple levels of rule and authority structures in their interactions with local actors. Whether these deliberative forms of governance lead to inclusive institutional and/or state building is debatable and more research is needed to understand how deliberative democracy operates in areas of limited statehood (Arda \& Banerjee, 2019).

Finally, there is a need for more research to understand the possibilities and limits of developing decolonial forms of deliberation based on Indigenous struggles. Decolonial perspectives on deliberative democracy can contribute to emerging scholarship on translocal governance by offering insights into democratization processes 'from below' that are more participatory than representative or deliberative forms of democracy because social relations are based on Indigenous notions of reciprocity and exchange rather than competition (Banerjee, 2018). Translocal governance reflects more horizontal relations between local communities instead of the vertical modes of governance that characterize relationships between a nation state and its citizens. These spaces offer possibilities of modes of existence not solely determined by market-state governance arrangements and can also create new sources of agency and translocal solidarities for communities. Horizontal alliances between communities can strengthen the legitimacy of local concerns thereby giving communities a stronger voice rather than a tokenistic presence in deliberations, including the right to say no to development and a refusal to participate in deliberative forums that are structurally unequal. The normative goal of translocal governance is not consensus, which as we have seen tends to disempower marginalized communities, but coexistence, self-determination and autonomy. Its legitimacy stems from Indigenous ecology-notions of community, territory, nature and culture embedded in Indigenous epistemologies and ontologies - with representative community councils as the structure of authority to make decisions that affect the community (Ballestrin, 2015). For instance, locally derived organizational forms such as gram sabhas in India or los caracoloes in Latin America are more representative of community concerns and reflect decolonial social relations. More research is needed to investigate how these organizations negotiate decisions with state and nonstate institutions. However, it is also important not to automatically privilege locally derived organizations but rather to demonstrate the same reflexivity used to problematize deliberative democracy in order to investigate if relations of domination in terms of class, caste, race, gender or sexual orientation exist in these organizational structures.

If democracy that is 'already here' cannot represent all its citizens equally and absolutely then its lack of closure implies there is a democracy 'always to come' (Derrida, 2005, p. 152). Democracy, according to Derrida is governed by an autoimmune logic, which works to preserve in itself the thing that both defines it and can destroy it: sovereignty. Democracy coopts sovereignty to immunize and protect itself from destruction but it can only do so by exercising a sovereignty that excludes, denies difference and homogenizes the multiplicity that is the basis of the formation of democracy in the first place, omissions 'that always return to haunt the supposed sovereignty of any political community, destroying the community's immunity from difference and otherness' (Matthews, 2013). One cannot imagine democracy without sovereignty, which when deployed to protect democracy ends up destroying it, but somewhat paradoxically this autoimmune flaw opens up new possibilities of a 'democracy to come'. The 'to come' does not just imply a temporality of the future but also 'possibilities for intervention, disruption, transformation and resistance that opens radically different horizons for democracy that is always to come....a democracy without end' (Matthews, 2013).

What would deliberate democracy look like from the perspective of groups who have been marginalized by an elite capture of discourses of development? If development in the postcolony requires 'sacrifice zones' in the name of 
national progress (Temper \& Martinez-Alier, 2013) then it becomes a matter of principle that those who are going to be sacrificed make that decision themselves (Zinn, 1980). This principle calls for 'epistemic disobedience' through a process of decolonizing knowledge with the aim of building just and democratic societies (Mignolo, 2009, p. 1). Decolonizing democracy can take place through articulations between the local and the global where the goal is less about creating an inclusive democracy but more a 'peaceful (or conflictive) coexistence in a given field of different models and practices of democracy' (Santos, 2005, p. 1xix). Deliberative democracy, despite efforts to be inclusive remains hegemonic and reflects a failure of the imagination because it normalizes difference and facilitates assimilation of dissenting groups within the dominant ideology. True difference can only be embodied by imagining a pluriverse, defined with such powerful clarity by the Zapatistas as a 'world where many worlds can coexist.'

\section{Declarations}

Conflict of interest The authors declare that they have no conflict of interest.

Open Access This article is licensed under a Creative Commons Attribution 4.0 International License, which permits use, sharing, adaptation, distribution and reproduction in any medium or format, as long as you give appropriate credit to the original author(s) and the source, provide a link to the Creative Commons licence, and indicate if changes were made. The images or other third party material in this article are included in the article's Creative Commons licence, unless indicated otherwise in a credit line to the material. If material is not included in the article's Creative Commons licence and your intended use is not permitted by statutory regulation or exceeds the permitted use, you will need to obtain permission directly from the copyright holder. To view a copy of this licence, visit http://creativecommons.org/licenses/by/4.0/.

\section{References}

Adorno, T., \& Horkheimer, M. (1972/1944). Dialectic of enlightenment. Continuum.

Alamgir, F., \& Banerjee, S. B. (2019). Contested compliance regimes in global production networks: Insights from the Bangladesh garment industry. Human Relations, 72(2), 272-297.

Alcadipani, R., Khan, F. R., Gantman, E., \& Nkomo, S. (2012). Southern voices in management and organization knowledge. Organization, 19, 131-143.

Amnesty International. (2019). The state of the world's human rights. Retrieved December 25, 2020 from, https://www.amnesty.org/ download/Documents/POL1067002018ENGLISH.PDF.

Anghie, A. (2005). Imperialism, sovereignty and the making of international law. Cambridge University Press.

Anzaldúa, G. (1987). Borderlands/la Frontera: The new Mestiza. Spinsters/Aunt Lute.
Arda, L., \& Banerjee, S. B. (2019). Governance in areas of limited statehood: The NGOization of Palestine. Business \& Society. https://doi.org/10.1177/0007650319870825

Ballestrin, L. (2015). Coloniality and democracy. Revista De Estudos Políticos, 5(1), 210-228.

Banerjee, S. B. (2000). Whose land is it anyway? National interest, indigenous stakeholders and colonial discourses: The case of the Jabiluka uranium mine. Organization \& Environment, 13(1), 3-38.

Banerjee, S. B. (2008). Necrocapitalism. Organization Studies, 29(12), 1541-1563.

Banerjee, S. B. (2018). Transnational power and translocal governance: The politics of corporate social responsibility. Human Relations, 71(6), 796-821.

Banerjee, S. B. (2021). Decolonizing management theory: A critical perspective. Journal of Management Studies. https://doi.org/ 10.1111/joms.12756

Banerjee, S. B., \& Arjaliès, D. L. (2021). Celebrating the end of Enlightenment: Organization theory in the age of the Anthropocene and Gaia (and why neither is the solution to our ecological crisis). Organization Theory. https://doi.org/10.1177/ 26317877211036714

Banerjee, S. B., \& Linstead, S. (2001). Globalization, multiculturalism and other fictions: Colonialism for the new millennium? Organization, 8(4), 683-722.

Banerjee, S. B., Maher, R., \& Kraemer, R. (2021). Resistance is fertile: Toward a political ecology of translocal resistance. Organization. https://doi.org/10.1177/1350508421995742

Banerjee, S. B., \& Prasad, A. (2008). Introduction to the special issue on 'Critical reflections on management and organizations: A postcolonial perspective.' Critical Perspectives on International Business, 4(2/3), 90-98.

Behrendt, L. (2003). Achieving social justice. Indigenous rights and Australia's future. Federation Press.

Belich, J. (2009). Replenishing the Earth. The settler revolution and the rise of the Anglo-World, 1783-1939. Oxford: Oxford University Press.

Bell, D. (2016). Reordering the world. Essays on liberalism and empire. Princeton University Press.

Benhabib, S. (2002). The claims of culture: Equality and diversity in the global era. Princeton University Press.

Bhambra, G. K. (2014). Postcolonial and decolonial dialogues. Postcolonial Studies, 17(2), 115-121.

Boussebaa, M. (2020). In the shadow of empire: Global Britain and the UK business school. Organization, 27(3), 483-493.

Boussebaa, M., Morgan, G., \& Sturdy, A. (2012). Constructing global firms? National, transnational and neocolonial effects in international management consultancies. Organization Studies, 33(4), 465-486.

Boussebaa, M., Sinha, S., \& Gabriel, Y. (2014). Englishization in offshore call centers: A postcolonial perspective. Journal of International Business Studies, 45(9), 1152-1169.

Brady, W. (2007). The sovereign being. In A. Moreton-Robinson (Ed.), Sovereign subjects (pp. 140-151). Allen \& Unwin.

Brand, T., Blok, V., \& Verweij, M. (2020). Stakeholder dialogue as agonistic deliberation: Exploring the role of Conflict and self-interest in business-NGO interaction. Business Ethics Quarterly, 30(1), 3-30.

Burg, R. (2009). Deliberative business ethics. Journal of Business Ethics, 88, 665-683.

Butt, N., Lambrick, F., Menton, M., \& Renwick, A. (2019). The supply chain of violence. Nature Sustainability, 2, 742-747.

Chakrabarty, D. (2000). Provincializing Europe: Postcolonial thought and historical difference. Princeton University Press. 
Chen, C., \& Mason, D. S. (2019). Making settler colonialism visible in sport management. Journal of Sport Management, 33(5), 379-392.

Clegg, S. R., \& Haugaard, M. (2009). The SAGE handbook of power. SAGE.

Crosby, A. W. (1986). Ecological imperialism: The biological expansion of Europe, 900-1900. Cambridge University Press.

Curato, N., Dryzek, J. S., Ercan, S. A., Hendriks, C. M., \& Niemeyer, S. (2017). Twelve key findings in deliberative democracy research. Daedalus, 146(3), 28-38.

Dalrymple, A. (2016). Tribe objected to pipeline nearly 2 years before lawsuit. Bismarck Tribune, November 30.

Dar, S. (2014). Hybrid accountabilities: When Western and nonWestern accountabilities Collide'. Human Relations, 67(2), 131-151.

Dar, S., Liu, H., Martinez Dy, A., \& Brewis, D. N. (2020). The business school is racist: Act up! Organization. https://doi.org/10. $1177 / 1350508420928521$

Dawkins, C. E. (2015). Agonistic pluralism and stakeholder engagement. Business Ethics Quarterly, 25(1), 1-28.

Dawkins, C. E. (2019). An agonistic notion of political CSR: Melding activism and deliberation. Journal of Business Ethics. https://doi.org/10.1007/s10551-019-04352-z

Derrida, J. (2005). Rogues: Two essays on reason. Stanford University Press.

Dhawan, N. (2014). Decolonizing Enlightenment: Transnational justice, human rights and democracy in a postcolonial world. Barbara Budrich Publishers.

Dirlik, A. (1994). The postcolonial aura: Third World criticism in an age of global capitalism. Critical Inquiry, 20, 328-356.

Dryzek, J. S. (2005). Deliberative democracy in divided societies: Alternatives to agonism and analgesia. Political Theory, 33(2), 218-242.

Dryzek, J. S. (2016). Symposium commentary: Reflections on the theory of deliberative systems. Critical Policy Studies, 10(2), 209-215.

Dussel, E. (2012). Transmodernity and interculturality: An interpretation from the perspective of philosophy of liberation. Transmodernity: Journal of Peripheral Cultural Production of the Luso-Hispanic World, 1(3), 28-59.

EJOLT. (2020). Mapping environmental justice. Environmental Justice Organizations, Liabilities and Trade. Retrieved December 25, 2020 from, http://www.ejatlas.org.

Ehrnström-Fuentes, M. (2016). Delinking legitimacies: A pluriversal perspective on political CSR. Journal of Management Studies, 53, 433-462.

Ehrnström-Fuentes, M. (2019). Confronting extractivism-The role of local struggles in the (un)making of place. Critical Perspectives on International Business. https://doi.org/10.1108/ cpoib-01-2018-0016

Ehrnström-Fuentes, M. (2020). Organising in defence of life: The emergence and dynamics of a territorial movement in Southern Chile. Organization. https://doi.org/10.1177/1350508420 963871

Ehrnström-Fuentes, M., \& Kröger, M. (2017). In the shadows of social licence to operate: Untold investment grievances in Latin America. Journal of Cleaner Production, 141, 346-358.

Ehrnström-Fuentes, M., \& Kröger, M. (2018). Birthing extractivism: The role of the state in forestry politics and development in Uruguay. Journal of Rural Studies, 57, 197-208.

Escobar, A. (2004). Beyond the Third World: Imperial globality, global coloniality and anti-globalization social movements. Third Word Quarterly, 25(1), 207-230.

Escobar, A. (2015). Degrowth, postdevelopment, and transitions: A preliminary conversation. Sustainability Science, 10, 451-462.
Escobar, A. (2018). Designs for the pluriverse: Radical interdependence, autonomy, and the making of worlds. Duke University Press.

Estes, N. (2019). Our history is our future. Verso.

Eze, E. C. (1997). Postcolonial African philosophy: A critical reader. Blackwell.

Fabian, J. (2002). Time and the other: How anthropology makes its object. Columbia University Press.

Faria, A., Ibarra-Colado, E., \& Guedes, A. (2010). Internationalization of management, neoliberalism and the Latin America Challenge. Critical Perspectives on International Business, 6(2/3), 97-115.

Fenn, E. A. (2000). Biological warfare in eighteenth-century North America: Beyond Jeffery Amherst. Journal of American History, 86(4), 1552-1580.

Fishkin, J. S., \& Mansbridge, J. (2017). The prospects and limits of deliberative democracy. Daedalus, 146(3), 6-13.

Flyvbjerg, B. (1998). Rationality and power. University of Chicago Press.

Forni, B. M. (2010). Political authority, recognition, and the rights of Indigenous peoples: An introduction. The Good Society, 19(2), 44-46.

Foucault, M. (1984). What is enlightenment? In P. Rabinow (Ed.), The Foucault Reader (pp. 32-50). Pantheon.

Fougère, M., \& Moulettes, A. (2012). Disclaimers, dichotomies and disappearances in international business textbooks: A postcolonial deconstruction. Management Learning, 43(1), 5-24.

Fougère, M., \& Solitander, N. (2020). Dissent in consensusland: An agonistic problematization of multi-stakeholder governance. Journal of Business Ethics, 164, 683-699. https://doi.org/10. 1007/s10551-019-04398-z

Fraser, N. (1990). Rethinking the public sphere: A contribution to the critique of actually existing democracy. Social Text, 25(26), $55-80$.

Frenkel, M. (2008). The multinational corporation as a third space: Rethinking international management discourse on knowledge transfer through Homi Bhabha. Academy of Management Review, 33(4), 924-942.

Frynas, J. G., \& Stephens, S. (2015). Political corporate social responsibility: Reviewing theories and setting new agendas. International Journal of Management Reviews, 17(4), 483-509.

Grosfoguel, R. (2007). The epistemic decolonial turn: Beyond political economy paradigms. Cultural Studies, 21(2-3), 211-223.

Grosfoguel, R. (2013). Decolonizing post-colonial studies and paradigms of political economy: Transmodernity, decolonial thinking, and global coloniality. TRANSMODERNITY: Journal of Peripheral Cultural Production of the Luso-Hispanic World, 1(1), 1-38

Gutmann, A., \& Thompson, D. (2018). Reflections on deliberative democracy: When theory meets practice. In A. Bächtiger, J. S. Dryzek, J. Mansbridge, \& M. Warren (Eds.), The Oxford handbook of deliberative democracy (pp. 901-915). Oxford University Press.

Habermas, J. (1975). Legitimation crisis. Beacon Press.

Habermas, J. (2001). The liberating power of symbols. Polity.

Habermas, J. (1998). Between facts and norms: Contributions to a discourse theory of law and democracy. W. Rehg (Trans.). MIT Press.

Harding, S. (2017). Latin American decolonial studies: Feminist issues. Feminist Studies, 43(3), 624-636.

Hegel, G. W. F. (1837/1916). Die Vernunft in der Geschichte. Kessinger Publishing.

Hendrix, B. (2010). Political authority and Indigenous sovereignty. The Good Society, 19(2), 47-52.

Hillier, J. (2003). Agon'izing over consensus: Why Habermasian ideals cannot be 'real.' Planning Theory, 2(1), 37-59. 
Hussain, N. (2003). The jurisprudence of emergency. The University of Michigan Press.

Hussain, W., \& Moriarty, J. (2018). Accountable to whom? Rethinking the role of corporations in political CSR. Journal of Business Ethics, 149, 519-534.

Ibarra-Colado, E. (2006). Organization studies and epistemic coloniality in Latin America: Thinking otherness from the margins. Organization, 13(4), 463-488.

Jack, G., Westwood, R., Srinivas, N., \& Sardar, Z. (2011). Deepening, broadening and re-asserting a postcolonial interrogative space in organization studies. Organization, 18(3), 275-302.

Kant, I. (1775/1950). On the different races of man. In E. W. Count (Ed.), This is race. Henry Schuman.

Kant, I. (1776/1978). Anthropology from a pragmatic point of view. Translated by V. L. Dowdell. Southern Illinois University Press.

Khan, F., Westwood, R., \& Boje, D. M. (2010). 'I feel like a foreign agent': NGOs and corporate social responsibility interventions into Third World child labor. Human Relations, 63(9), $1417-1438$.

Koelble, T. A., \& Lipuma, E. (2008). Democratizing democracy: A postcolonial critique of conventional approaches to the measurement of democracy. Democratisation, 15(1), 1-28.

Van Lent, W., \& Smith, A. D. (2019). Using versus excusing: The Hudson's Bay Company's long-term engagement with its (problematic) past. Journal of Business Ethics, 166, 215-231.

Levy, D., Reinecke, J., \& Manning, S. (2016). The political dynamics of sustainable coffee: Contested value regimes and the transformation of sustainability. Journal of Management Studies, 53(3), 364-401.

Lugones, M. (2010). Toward a decolonial feminism. Hypatia, 25(4), $742-759$.

Mandiola, M. P. (2010). Latin America's critical management? A liberation genealogy. Critical Perspectives on International Business, 6(2/3), 162-176.

Manning, J. (2018). Becoming a decolonial feminist ethnographer: Addressing the complexities of positionality and representation. Management Learning, 49(3), 311-326.

Matthews, D. (2013). The democracy to come: Notes on the thought of Jacques Derrida. Critical Legal Thinking. http://criticallegalth inking.com/2013/04/16/the-democracy-to-come-notes-on-thethought-of-jacques-derrida/

Mehrpouya, A., \& Willmott, H. (2018). Making a niche: The marketization of management research and the rise of 'knowledge branding.' Journal of Management Studies, 55(4), 728-734.

Mignolo, W. D. (2000). Local histories/global designs: Essays on the coloniality of power, subaltern knowledges and border thinking. Princeton University Press.

Mignolo, W. D. (2009). Epistemic disobedience, independent thought and de-colonial freedom. Theory, Culture \& Society, 26(7-8), $1-23$.

Mignolo, W., \& Walsh, C. (2018). On decoloniality: Concepts, analytics, praxis. Duke University Press.

Misoczky, M. C. (2011). World visions in dispute in contemporary Latin America: Development x harmonic life. Organization, 18(3), 345-363.

Misoczky, M. C. (2019). Contributions of Aníbal Quijano and Enrique Dussel for an anti-management perspective in defence of life. Cuadernos de Administracion. https://doi.org/10.11144/Javer iana.cao32-58.caqed

Moog, S., Spicer, A., \& Böhm, S. (2015). The politics of multi-stakeholder initiatives: The crisis of the Forest Stewardship Council. Journal of Business Ethics, 128, 469-493.

Mouffe, C. (1999). Deliberative democracy or agonistic pluralism? Social Research, 66(3), 745-758.
Mäkinen, J., \& Kourula, A. (2012). Pluralism in political corporate social responsibility. Business Ethics Quarterly, 22, 649-678.

Naude, P. (2019). Decolonising knowledge: Can Ubuntu ethics save us from coloniality? Journal of Business Ethics, 159, 23-37.

Nkomo, S. M. (2011). A postcolonial and anti-colonial reading of 'African' leadership and management in organization studies: Tensions, contradictions and possibilities. Organization, 18(3), $365-386$.

Ong, A. (2000). Graduated sovereignty in south-east Asia. Theory Culture and Society, 17(4), 55-75.

Özkazanç-Pan, B. (2008). International management research meets the rest of the world. Academy of Management Review, 33(4), 964-974.

Özkazanç-Pan, B. (2019). CSR as gendered neocoloniality in the global south. Journal of Business Ethics, 160, 851-864.

Prasad, A. (Ed.). (2003). Postcolonial theory and organizational analysis: A critical engagement. Palgrave Macmillan/St. Martin's Press.

Prasad, A., \& Qureshi, T. (2016). Race and racism in an elite postcolonial context: Reflections from investment banking. Work, Employment \& Society, 31(2), 352-362.

Preston, J. (2013). Neoliberal settler colonialism, Canada and the tar sands. Race \& Class, 55(2), 42-59.

Quijano, A. (2000). Coloniality of power, ethnocentrism, and Latin America. NEPANTLA, 1(3), 533-580.

Quijano, A. (2007). Coloniality and modernity/rationality. Cultural Studies, 21(2), 168-178.

Rhodes, C., \& Fleming, P. (2020). Forget political corporate social responsibility. Organization, 27(6), 943-951.

Risse, T. (2011). Governance in areas of limited statehood. In T. Risse (Ed.), Governance without a State? Policies and politics in areas of limited statehood (pp. 1-36). Columbia University Press.

Sabadoz, C., \& Singer, A. (2017). Talk ain't cheap: Political CSR and the challenges of corporate deliberation. Business Ethics Quarterly, 27(2), 183-211.

Said, E. W. (1993). Culture and imperialism. Knopf.

Sanders, D. (1999). Indigenous peoples: Issues of definition. International Journal of Cultural Property, 8(1), 4-13.

Santos, B. S. (2005). Democratizing democracy: Beyond the liberal democratic canon. Verso.

Scherer, A. G., \& Palazzo, G. (2011). The new political role of business in a globalized world: A review of a new perspective on CSR and its implications for the firm, governance and democracy. Journal of Management Studies, 48(4), 899-929.

Scherer, A. G., Rasche, A., Palazzo, G., \& Spicer, A. (2016). Managing for political corporate social responsibility: New challenges and directions for PCSR 2.0. Journal of Management Studies, 53(3), 273-298.

Shrivastava, A., \& Kothari, A. (2012). Churning the earth: The making of global India. Penguin Viking.

Srinivas, N. (2013). Could a subaltern manage? Identity work and habitus in a colonial workplace. Organization Studies, 34(11), $1655-1674$.

Srinivas, N. (2020). False binaries in management history, and the scope for a postcolonial project. Journal of Management History, 27(10), 121-140.

Stanley, A. (2019). Aligning against Indigenous jurisdiction: Worker savings, colonial capital, and the Canada Infrastructure Bank. Environment and Planning d: Society and Space, 37(6), $1138-1156$

Temper, L., \& Martinez-Alier, J. (2013). The god of the mountain and Godavarman: Net present value, indigenous territorial rights and sacredness in a bauxite mining conflict in India. Ecological Economics, 96, 79-87. 
Tooze, A. (2006). The wages of destruction: The making and breaking of the Nazi economy. Allen Lane.

Tuck, E., \& Yang, K. W. (2012). Decolonization is not a metaphor. Decolonization: Indigeneity, Education \& Society, 1(1), 1-40.

Tully, J. (2008). Public philosophy in a new key. Cambridge University Press.

US Department of State. (2010). Announcement of US support for the United Nations Declaration on the Rights of Indigenous Peoples. Retrieved December 25, 2020 from, https://2009-2017.state.gov/ documents/organization/184099.pdf.

United Nations. (2007). Declaration of the rights of Indigenous peoples. Retrieved December 25, 2020, from https://www.un.org/ development/desa/indigenouspeoples/declaration-on-the-rightsof-indigenous-peoples.html.

Varman, R., \& Al-Amoudi, I. (2016). Accumulation through derealization: How corporate violence remains unchecked. Human Relations, 69(10), 1909-1935.

Veracini, L. (2011). Introducing: Settler colonial studies. Settler Colonial Studies, 1(1), 1-12.

Veracini, L. (2013). Settler colonialism: Career of a concept. The Journal of Imperial and Commonwealth History, 41(2), 313-333.

Volmert, A. (2010). Indigenous self-determination and freedom from rule. The Good Society, 19(2), 53-59.

Wanderley, S., \& Faria, A. (2012). The Chandler-Furtado case: A decolonial re-framing of a North/South (dis)encounter. Management \& Organizational History, 7(3), 219-236.

Watson, I. (2006). Aboriginal sovereignties: Past, present and future (im)possibilities. In S. Perera (Ed.), Our Patch: Enacting Australian Sovereignty Post 2001 (pp. 23-44). Network Books.
Westwood, R. (2006). International business and management studies as an Orientalist discourse: A postcolonial critique. Critical Perspectives on International Business, 2(2), 91-113.

Westwood, R., \& Jack, G. (2007). Manifesto for a post-colonial international business and management studies: A provocation. Critical Perspectives on International Business, 3(3), 246-265.

Whelan, G. (2012). The political perspective of corporate social responsibility: A critical research agenda. Business Ethics Quarterly, 22(4), 709-737.

Willke, H., \& Willke, G. (2008). Corporate moral legitimacy and the legitimacy of morals: A critique of Palazzo/Scherer's communicative framework. Journal of Business Ethics, 81, 27-38.

Winsor, M. (2019). Over 380,000 gallons of oil spill from Keystone pipeline in North Dakota. ABC News. https://abcnews.go.com/ US/380000-gallons-oil-spill-keystone-pipeline-north-dakota/ story? $\mathrm{id}=66683075$.

Wolfe, P. (2006). Settler colonialism and the elimination of the native. Journal of Genocide Research, 8(4), 387-409.

Yousfi, H. (2013). Rethinking hybridity in postcolonial Contexts: What changes and what persists? The Tunisian case of Poulina's managers. Organization Studies, 35, 393-421.

Zinn, H. (1980). A people's history of the United States. Harper \& Row.

Publisher's Note Springer Nature remains neutral with regard to jurisdictional claims in published maps and institutional affiliations. 